\title{
Плазмоника наночастиц со спиновой поляризацией
}

\author{
В.П. Драчев ${ }^{1,2, *}$ Хари Бхатта ${ }^{2}$, Али Алиев ${ }^{3}$ \\ ${ }^{1}$ Сколковский Интситут Науки и Технологий, Москва, Россия 121205 \\ ${ }^{2}$ Department of Physics, University of North Texas, Denton, TX, USA 76203 \\ ${ }^{3}$ A. G. MacDiarmid NanoTech Institute, University of Texas at Dallas, Richardson, TX, USA 75080 \\ *E-mail: v.drachev@skoltech.ru
}

DOI:10.31868/RFL2018.26

Металлические частицы малых размеров поддерживают возбуждение локализованных плазмонов. Возникающие при этом высокие локальные поля являются основной причиной усиления оптических откликов, линейных и особенно нелинейных. Такие эффекты как гигантское комбинационное рассеяние, усиление фотолюминесценции, усиление радиационной релаксации возбуждения, зависимость от геометрии металлических наноструктур нашли применение в сенсорах, оптоэлектронике и метаматериалах.

Магнитные наночастицы никогда не рассматривалась в качестве скольконибудь приемлемых кандидатов для плазмонных применений из-за низкой проводимости. Оптические измерения в УФ/Видимом/ИК диапазоне для тонких пленок и наночастиц подтверждали это мнение.

Результаты наших экспериментов показали неожиданно высоко-добротный плазмонный резонанс в наночастицах Со. Длина волны этого резонанса находится в ультрафиолетовой части спектра, 275 нм. Плазмонный резонанс хорошего качества в УФ диапазоне, где многие биомолекулы имеют электронные резонансы, делает наночастицы Со привлекательным материалом для биосенсоров.

В докладе будут обсуждаться результаты спектральных, структурных и магнитных измерений наночастиц Со синтезированных нами в растворе гексана. Наши выводы основаны на представлении об однодоменных частицах с поляризацией спинов, где присутствуют два независимых канала проводимости для электронов с противоположными спинами и с сильно разными константами релаксации электронов. Синтез таких частиц требует специальных условий, что объясняет отличие наших результатов от литературных данных. 